\title{
Essential Oil of Baccharis dracunculifolia (Asteraceae) Decreases Alternaria Rot in Pitahaya
}

\author{
Daniel Debona ${ }^{1}$, Angela Pivotto ${ }^{1}$, Alexsandro J. Tetzlaff ${ }^{1}$, Darlan F. Sartori $^{1}$, Luiz A. Borelli ${ }^{1}$, \\ Murilo S. de Oliveira $^{2}$, Lilian Y. Yamamoto ${ }^{3} \&$ Jociani Ascari $^{2}$ \\ ${ }^{1}$ Laboratory of Plant Health, Universidade Tecnológica Federal do Paraná-Câmpus Santa Helena, Santa Helena, \\ Paraná, Brazil \\ ${ }^{2}$ Laboratory of Chemistry, Universidade Tecnológica Federal do Paraná-Câmpus Santa Helena, Santa Helena, \\ Paraná, Brazil \\ ${ }^{3}$ Laboratory of Food Analysis and Processing, Universidade Tecnológica Federal do Paraná-Câmpus Santa \\ Helena, Santa Helena, Paraná, Brazil \\ Correspondence: Daniel Debona, Laboratory of Plant Health, Universidade Tecnológica Federal do Paraná, \\ Câmpus Santa Helena, Santa Helena, Paraná 85892-000, Brazil. E-mail: debona@utfpr.edu.br
}

Received: April 20, 2021

doi:10.5539/jas.v13n7p10

\author{
Accepted: May 19, 2021 \\ Online Published: June 15, 2021 \\ URL: https://doi.org/10.5539/jas.v13n7p10
}

\begin{abstract}
Alternaria rot, caused by Alternaria alternata, is one of the most destructive diseases of pitahaya (Hylocereus spp.). We investigated the effect of the essential oil of Baccharis dracunculifolia (Asteraceae) (EOB) in the control of A. alternata. Two studies were performed in Petri dishes containing potato dextrose agar medium amended with concentrations of the EOB ranging from 5 to $1,000 \mu \mathrm{g} \mathrm{mL} \mathrm{m}^{-1}$ (first study) and from 30 to $2,000 \mu \mathrm{g}$ $\mathrm{mL}^{-1}$. The diameter of the fungal colony was recorded daily. These data were used to calculate the the area under the mycelial growth progress curve (AUMGPC) and mycelial growth index (MGI). In the third study, the control of Alternaria rot in pitahaya fruits by EOB was investigated by adding the EOB into an edible coat based on cassava starch and sorbitol which was prepared in Tween 20. Three treatments, containing EOB at 500, 1,000 or $2,000 \mu \mathrm{g} \mathrm{mL}^{-1}$, were assessed. Two additional treatments, one containing water and another containing only the edible coating served as controls. Pitahaya fruits were immersed in those solutions for $10 \mathrm{~min}$, allowed to dry and inoculated with $A$. alternata $48 \mathrm{~h}$ later. The EOB was found to inhibit the mycelial growth and a negative and quadratic model best described the relationship of the EOB concentrations with MGI and AUMGPC. Results from the experiment performed with pitahaya fruits showed that Alternaria rot was decreased with increasing EOB concentrations. Therefore, EOB is a promising and ecofriendly method that may be included in the management of Alternaria rot in pitahya.
\end{abstract}

Keywords: Alternaria alternata, Hylocereus undatus, alternative control, fruit rot, mycelial growth inhibition

\section{Introduction}

Pitahaya (Hylocereus undatus Haw.), also known as dragon fruit, is a member of the Cactaceae family that is native to the tropical forest regions of Mexico and Central and South Amercia (Mizrahi et al., 1997). The fruit has received great attention in the recent years not only due to its attractive color and economic value as food products, but especially for its health properties (Kim et al., 2011). Health benefits of pitahaya are linked to its remarkable antioxidant activity conferred by its betacyanin content (Wybranice et al., 2007), decreasing cholesterol levels and preventing diseases such as cancer and hypertension besides having anti-inflammatory and antidiabetic effects, and reducing the risk of cardiovascular disease (Stintzing et al., 2002; Cos et al., 2004; Wahdaningsih et al., 2020).

Since pitahaya is a newly cultivated crop, postharvest studies have been limited. In natural conditions, fruits keep quality around six to eight days after harvesting, whereas an inadequate handling and environment results in quicker deterioration, decreasing shelf life and compromising its commercial value (Castro et al., 2017; Chaemsanit et al., 2018). Given the lack of studies, research-based information to develop postharvest techniques that maintain fruit quality and increase fruit availability in the marketplace are needed (Freitas \& Mitcham, 2013). 
Beyond fruit losses caused during handling, transport and storage, postharvest diseases dramatically contribute to fruit deterioration, resulting in black spots, necrosis, rot, and deterioration, making the fruit unsuitable for consumption and resulting in disposal (Ortiz-Hernández \& Carrillo-Salazar, 2012; Castro et al., 2017). Alternaria spp. is widely spread in the environment, encompassing numerous saprophytic, endophytic and plant pathogenic species, causing deterioration in cereals, fruits and vegetables both in pre- and post-harvest (Garganese et al., 2016). Recently, macro- and micro-morphological analysis confirmed the presence of Alternaria alternata causing deterioration and rot in pitahaya fruits during storage (Castro et al., 2017).

Essential oils have emerged as a promising and ecofriendly alternative for plant disease control. Indeed, some essential oils have demonstrated to be effective against Alternaria spp. Immersion of carrot seeds in both the neem and the orange essential oils displayed lower A. alternata incidence regardless of their concentration; the effect of the essential oils was similar to that of a standard fungicide applied as seed treatment (Lima et al., 2016) The growth of $A$. padwickii was completely inhibited by the essential oils of Callistemon citrinus and Cymbopogon citratus (Nguefack et al., 2013). Similarly, the essential oils of Cinnamomum zeylanicum and Eucalyptus caryophyllus were suggested to be promising for the control of A. alternata, since they were active against the fungus (Castro et al., 2017).

Baccharis dracunculifolia (Asteraceae) is native plant from Brazil, commonly known as 'Alecrim-do-campo' and is widely used in folk medicine to treat inflammation, hepatic disorders and stomach ulcers (Massignani et al., 2009). However, to the best of our knowledge, such species have not been investigated for its potential in the control of plant pathogens. In the present work, we performed in vitro and in vivo analysis to investigate whether the essential oil of $B$. dracunculifolia is active against $A$. alternata and, in turn, decreases the symptoms of Alternaria rot in pitahaya fruits.

\section{Material and Methods}

\subsection{Pathogen Isolation}

Pitahaya fruits displaying Alternaria rot symptoms were collected in Marialva, Paraná State, Brazil. Fruits were washed in tap water with soap, rinsed and allowed to dry. Epidermal sections of $1 \mathrm{~cm}^{2}$ in the transition between symptomatic and asymptomatic region were removed from the fruits. Fragments were immersed in alcohol (70\%) for 30 seconds, sodium hypochloride $(0.5 \%)$ for 1 minute and distilled sterile water (three times) for 1 minute. Then, fruit segments were allowed to dry in a sterile filter paper and transferred into Petri dishes containing potato dextrose agar (PDA) medium. Petri dishes were incubated at $28{ }^{\circ} \mathrm{C}$ for 7 days. Alternaria alternata was identified according Castro et al. (2017), who isolated the fungus from pitahaya fruits in the same municipality.

\subsection{Plant Material Collection and Identification and Extraction of the Essential Oil}

Mature leaves of B. dracunculifolia were collected in May 2018, in the municipality of Santa Helena city

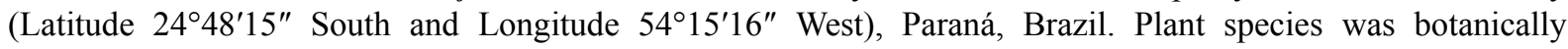
identified at the Herbarium ECT (Embrapa Clima Temperado, Pelotas, Rio Grande do Sul, Brazil) and exsiccates were deposited with registration number ECT0003428. Plant material was processed and the essential oil was analyzed as reported by Brandenburg et al. (2020). Plant material was dried at room temperature $\left(24{ }^{\circ} \mathrm{C}\right)$ for 4 days. Thus, leaves were hydrodistilled for 3 hours using a Clevenger-type apparatus (Stahl \& Schild, 1981). The essential oils obtained were separated from the hydrolates using ethyl ether, the organic phases were dried with anhydrous $\mathrm{Na}_{2} \mathrm{SO}_{4}$, filtered and the solvent was evaporated under vacuum at low temperature. The yields of the essential oil samples were calculated by considering the dry mass of each starting material (Ascari et al., 2019).

\subsection{Essential Oil of Baccharis dracunculifolia and Its Effect in the Mycelial Growth of Alternaria alternata}

Two experiments were performed in the Laboratory of Plant Health at the Universidade Tecnológica Federal do Paraná-Campus Santa Helena to investigate the inhibitory activity of the essential oil of $B$. dracunculifolia (EOB) in the mycelia growth of A. alternata.

Six concentrations of the EOB were assessed for each experiment. EOB concentration ranged from 5 (T2) to $1,000 \mu \mathrm{g} \mathrm{mL}^{-1}$ (T7) for the first study and from 30 (T2) to $2,000 \mu \mathrm{g} \mathrm{mL}^{-1}$ (T7) for the second one. EOB concentrations were calculated based on a geometric progression. Such concentrations were obtained from a stock solution of the EOB was prepared in 1\% Tween 20. In both experiments, a solution of $1 \%$ Tween 20 served as control (T1).

Each concentration of EOB was added to the melted $\left(\sim 45^{\circ} \mathrm{C}\right)$ potato dextrose agar (PDA) medium with the aid of a pipette. Thus, the culture medium was poured into Petri dishes (100 $\mathrm{mm}$ in diameter). After culture medium was solidified, a $5 \mathrm{~mm}$ mycelial disc of A. alternata was removed from the edge of 7 days old colony and 
transferred to the center of the Petri dishes of each treatment. Petri dishes were incubated in a BOD chamber at $25^{\circ} \mathrm{C}$ and a $12 \mathrm{~h}$ photoperiod.

Mycelial growth of A. alternata colony of each treatment was assessed daily from $48 \mathrm{~h}$ onwards using a digital caliper. Assessements proceed until the fungus grew over throughout the PDA medium in the control treatment. Colony diameter was determined in two orthogonal directions and mean diameter was calculated. Data from mean diameter were used to calculate the mycelial growth index (1) and the area under the mycelial growth progress curve (2) as they folow:

$$
\mathrm{MGI}=\sum(\mathrm{D}-\mathrm{Dp}) /(\mathrm{Tp}-\mathrm{T})
$$

where, MGI = mycelial growth index; $\mathrm{D}=$ actual mean diameter $(\mathrm{mm})$ of the colony; $\mathrm{Dp}=$ mean diameter $(\mathrm{mm})$ of the colony in the previous day; $\mathrm{T}=$ time of the assessment made at " $\mathrm{D}$ "; $\mathrm{Tp}=$ time of the assessment made at "Dp".

$$
\text { AUMGPC }=\sum\left(\mathrm{D}+\mathrm{D}_{\mathrm{p}}\right) / 2 \times(\mathrm{Tp}-\mathrm{T})
$$

where, AUMGPC = area under the mycelial growth progress curve; $\mathrm{D}=$ actual mean diameter $(\mathrm{mm})$ of the colony; $\mathrm{Dp}=$ mean diameter $(\mathrm{mm})$ of the colony in the previous day; $\mathrm{T}=$ time of the assessment made at " $\mathrm{D}$ "; $\mathrm{Tp}=$ time of the assessment made at "Dp".

\subsection{Essential Oil of Baccharis dracunculifolia in the Control of Alternaria Rot in Pitahaya Fruits}

One experiment was performed in the Laboratory of Plant Health at the Universidade Tecnológica Federal do Paraná-Campus Santa Helena to investigate whether EOB incorporated into an edible coat controls Alternaria rot in pitahaya fruits. The edible coat has been researched aiming at increasing shelf life of pitahaya fruits.

Pitahaya fruits (Hylocereus undulatus) of approximately $15 \mathrm{~cm}$ in length and $10 \mathrm{~cm}$ in diameter were collected in Marialva, Paraná State, Brazil. Fruits were transported to the place were the experiment was carried out and they were surface-disinfested for $5 \mathrm{~min}$ in $0.5 \%$ sodium hypochloride. Only fruits that did not show injury or disease symptoms and which had approximately the same size were used in the study. Concentrations of EOB that were most inhibitory in vitro were assessed in this study. The following treatments were evaluated: negative control (T1), EOB at $500 \mu \mathrm{g} \mathrm{mL}^{-1}$ (T2), EOB at $1,000 \mu \mathrm{g} \mathrm{mL}^{-1}$ (T3), EOB at 2,000 $\mu \mathrm{g} \mathrm{mL}^{-1}$ (T4) and positive control (T5). The edible coat was composed of cassava starch $(3 \%)$, Tween $20(1 \mathrm{~mL})$ and sorbitol $(4 \mathrm{~mL})$. Tween 20 and sorbitol were added to improve plasticizing characteristic. The negative control (T1) and positive control (T5) were composed of distilled water and the edible coat without the EOB.

Cassava starch-based coat was prepared by heating the suspension (cassava starch and water) to $70{ }^{\circ} \mathrm{C}$. The suspension was allowed to cool at room temperature $\left(25^{\circ} \mathrm{C}\right)$ and Tween, sorbitol and EOB were then added. Fruits were immersed in the solutions for 2 min and placed on screens until the coating was completely dried. Fruits were transferred to a BOD chamber at $25^{\circ} \mathrm{C}$ and a $12 \mathrm{~h}$ photoperiod for $48 \mathrm{~h}$, when they were inoculated with A. alternata.

Pitahaya fruits were inoculated with a mycelial disc of $A$. alternata. The fungus was grown in Petri dishes (100 $\mathrm{mm}$ in diameter) containing BDA culture medium and were incubated in a BOD chamber at $25{ }^{\circ} \mathrm{C}$ and a $12 \mathrm{~h}$ photoperiod. Inoculation was carried out under fruit scales after making a hole ( $3 \mathrm{~mm}$ in depth) with needle tip. Two holes in opposed sides at the middle region of the fruit were made and then a mycelial disc $(5 \mathrm{~mm}$ in diameter) of A. alternata was placed over each hole. Mycelial discs were removed from the edge of fungal colony 7 days after incubation. After inoculation, fruits were placed in polypropylene trays that were covered with moistened plastic bags. The fruits were then incubated in a BOD chamber at $25^{\circ} \mathrm{C}$ for 7 days, when disease assessments were performed. The diameter of Alternaria rot lesions was determined using a digital caliper. Measurements were took in the two orthogonal directions considering the largest diameter of the lesion in each edge. Mean diameter was obtained and values were expressed as lesion area $\left(\mathrm{cm}^{2}\right)$.

\subsection{Statistical Analysis and Experimental Design}

For in vitro assays, seven treatments with five replications were assessed, whereas five treatments with five replications were employed for in vivo assays. Each experimental unit consisted in a Petri dish (in vitro assays) or a pitahaya fruit (in vivo assays). All studies were conducted in a completely randomized design. Data were subjected to the analysis of variance (ANOVA). Data from the in vitro studies were subjected to regression analysis, whereas means obtained for in vivo assays were compared based on the Tukey's test $(P \leq 0.05)$. Statistical analysis was performed using the software Minitab 16. 


\section{Results}

Twelve days after incubation, colony of A. alternata grew throughout over the BDA medium in Petri dishes of the control treatment (Figure 1). Low concentrations $\left(<70 \mu \mathrm{g} \mathrm{mL}^{-1}\right.$; T2 and T3) of the essential oil of $B$. dracunculifolia (EOB) almost did not inhibit the mycelial growth of the fungus, whereas a small inhibition was observed in concentrations between 160 and $373 \mu \mathrm{g} \mathrm{mL}^{-1}$ (T4 and T5). When EOB concentrations were higher than $860 \mu \mathrm{g} \mathrm{mL}^{-1}$ (T6 and T7), the highest inhibitory effect was observed.
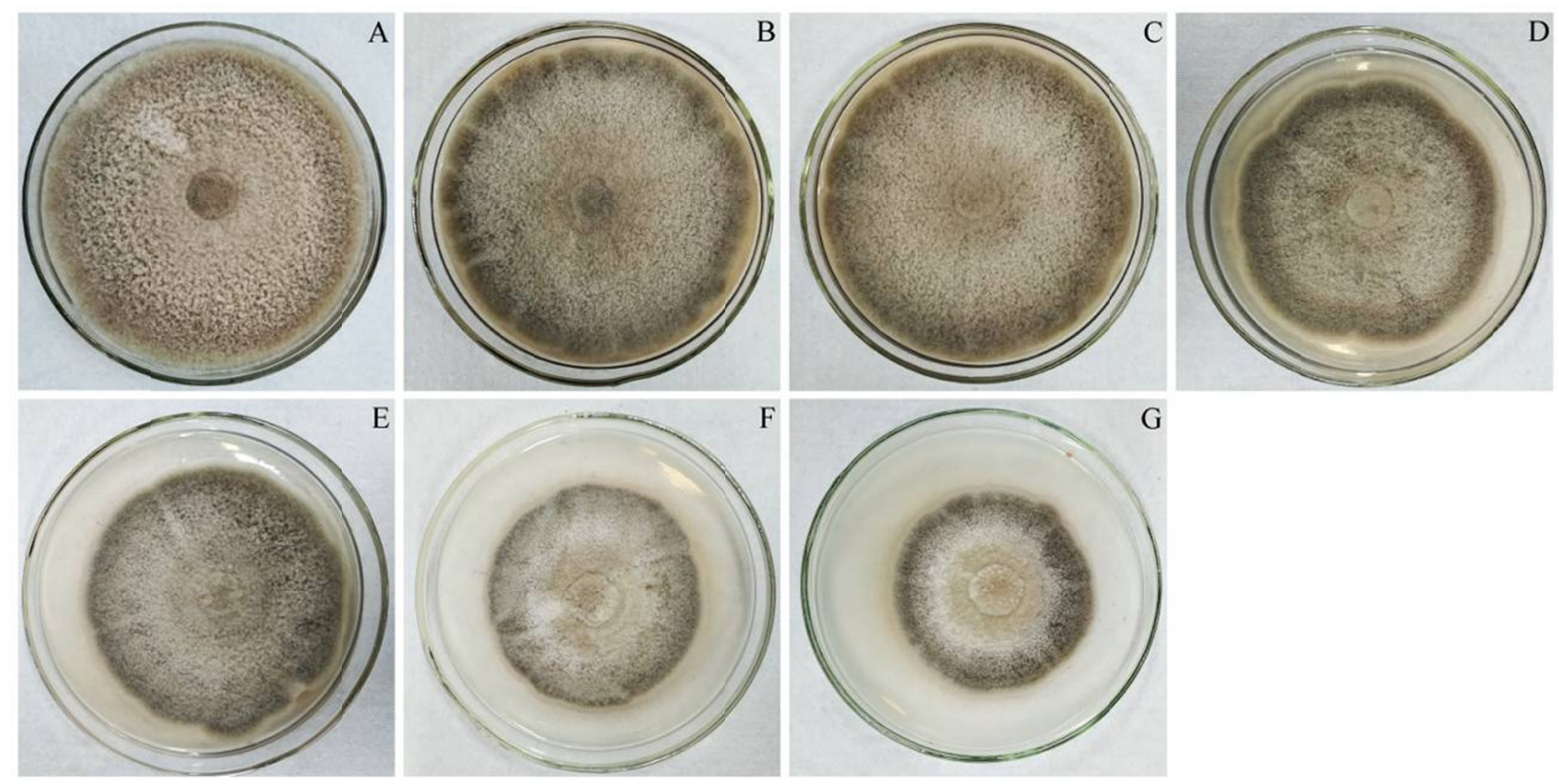

Figure 1. Effect of different concentrations of the essential oil of Baccharis dracunculifolia (EOB) in the mycelial growth of Alternaria alternata. Treatments included a control without EOB (A) and the EOB concentrations of 29.99 (B), 69.47 (C), 160.92 (D), 372.73 (E), 863.38 (F) or $1999.86 \mu \mathrm{g} \mathrm{mL}^{-1}(\mathrm{G})$

The progress curve of mycelial growth for the first in vitro assay showed that low concentrations of EOB $(<42$ $\left.\mu \mathrm{g} \mathrm{mL}{ }^{-1} ; \mathrm{T} 2-\mathrm{T} 4\right)$ were similar to the control (T1) and a slight inhibition was observed in BDA amended with EOB at $120 \mu \mathrm{g} \mathrm{mL} \mathrm{m}^{-1}$ (T5). There was a higher inhibitory effect when EOB was used at the concentrations of 346 (T6) and 1,000 $\mu \mathrm{g} / \mathrm{mL}$ (T7) (Figure 2A). The treatments T5, T6 and T7 decreased the final colony diameter by 8 , 24 and $29 \%$ relative to the control.

A negative and quadratic model best fitted to describe the relationship between EOB concentrations and AUMGPC and MGI (Figures 2B and 2C). The lowest values of AUMGPC and MGI were obtained at the EOB concentrations of 950 and $500 \mu \mathrm{g} \mathrm{mL} L^{-1}$, respectively. 

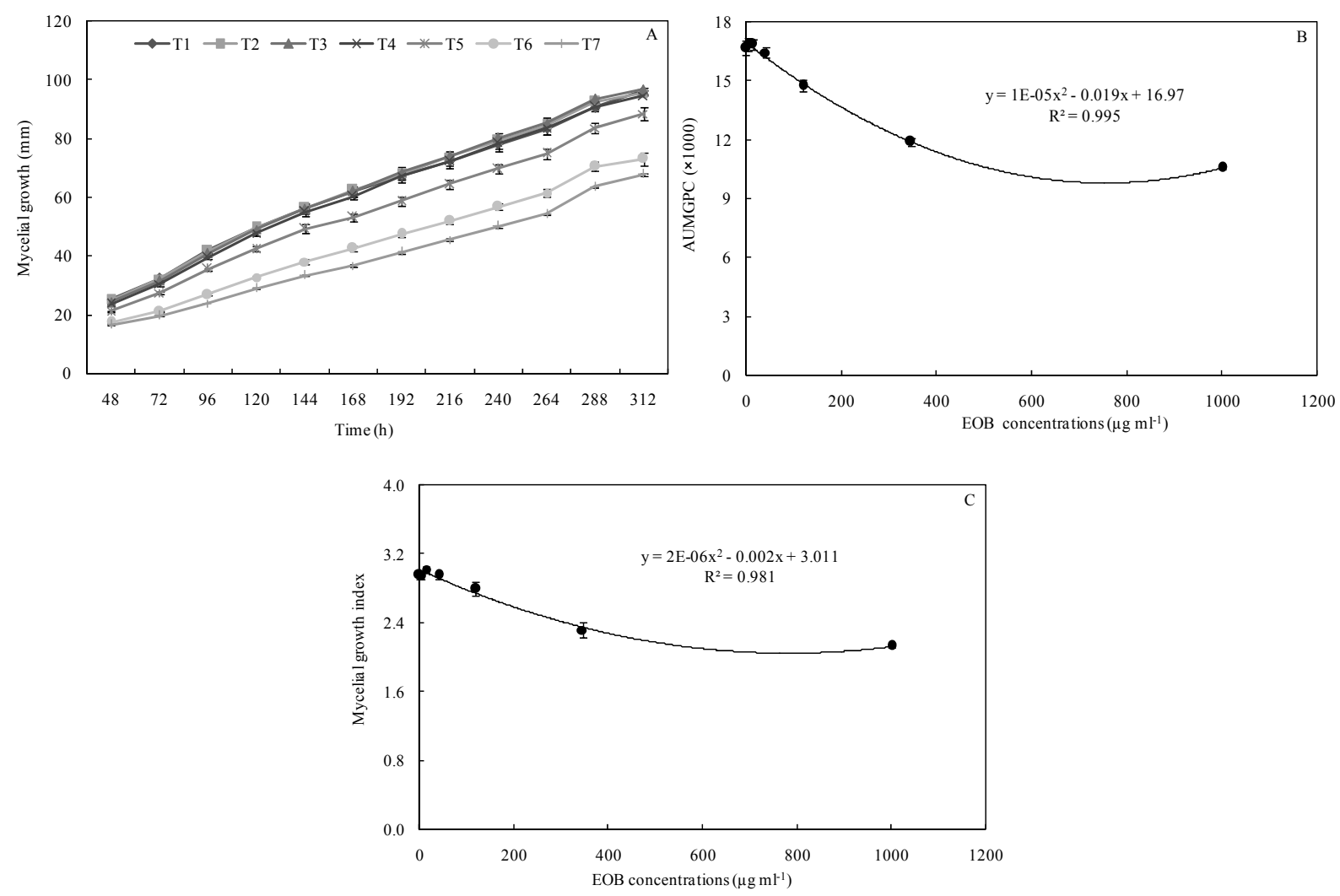

Figure 2. Effect of different concentrations of the essential oil of Baccharis dracunculifolia (EOB) in the mycelial growth of Alternaria alternata $(\mathrm{mm})(\mathrm{A})$, area under the mycelial growth progress curve $(\mathrm{B})$ and mycelial growth índex (C). Treatments included a control without EOB (T1) and the EOB concentrations of 5 (T2), 14.42 (T3), 41.62 (T4), 120.09 (T5), 346.05 (T6) or $999.97 \mu \mathrm{g} \mathrm{mL}^{-1}$ (T7).

Bars represent standard errors of the means $(n=5)$

In agreement with visual observations of Petri dishes, assessments of colony diameter made in the second in vitro assay revealed none and a slight inhibitory effect of low $\left(<70 \mu \mathrm{g} \mathrm{mL}^{-1} ; \mathrm{T} 2\right.$ and T3) and intermediate (161 and $373 \mu \mathrm{g} \mathrm{mL}^{-1}$; T4 and T5) EOB concentrations, respectively (Figure 3A). Higher inhibitory effect was observed for EOB used at 863 (T6) and 2,000 $\mu \mathrm{g} \mathrm{mL}^{-1}$ (T7). Colony diameter in the last assessment was reduced by $14,14,32$ and $34 \%$ for T4, T5, T6 and T7, respectively, in comparison to the control.

The relationship between EOB concentrations and AUMGPC and MGI was best described by a negative and quadratic model (Figures $3 \mathrm{~B}$ and $3 \mathrm{C}$ ). The $\mathrm{EOB}$ concentration of $1250 \mu \mathrm{g} \mathrm{mL}^{-1}$ resulted in the lowest values for both AUMGPC and MGI. 

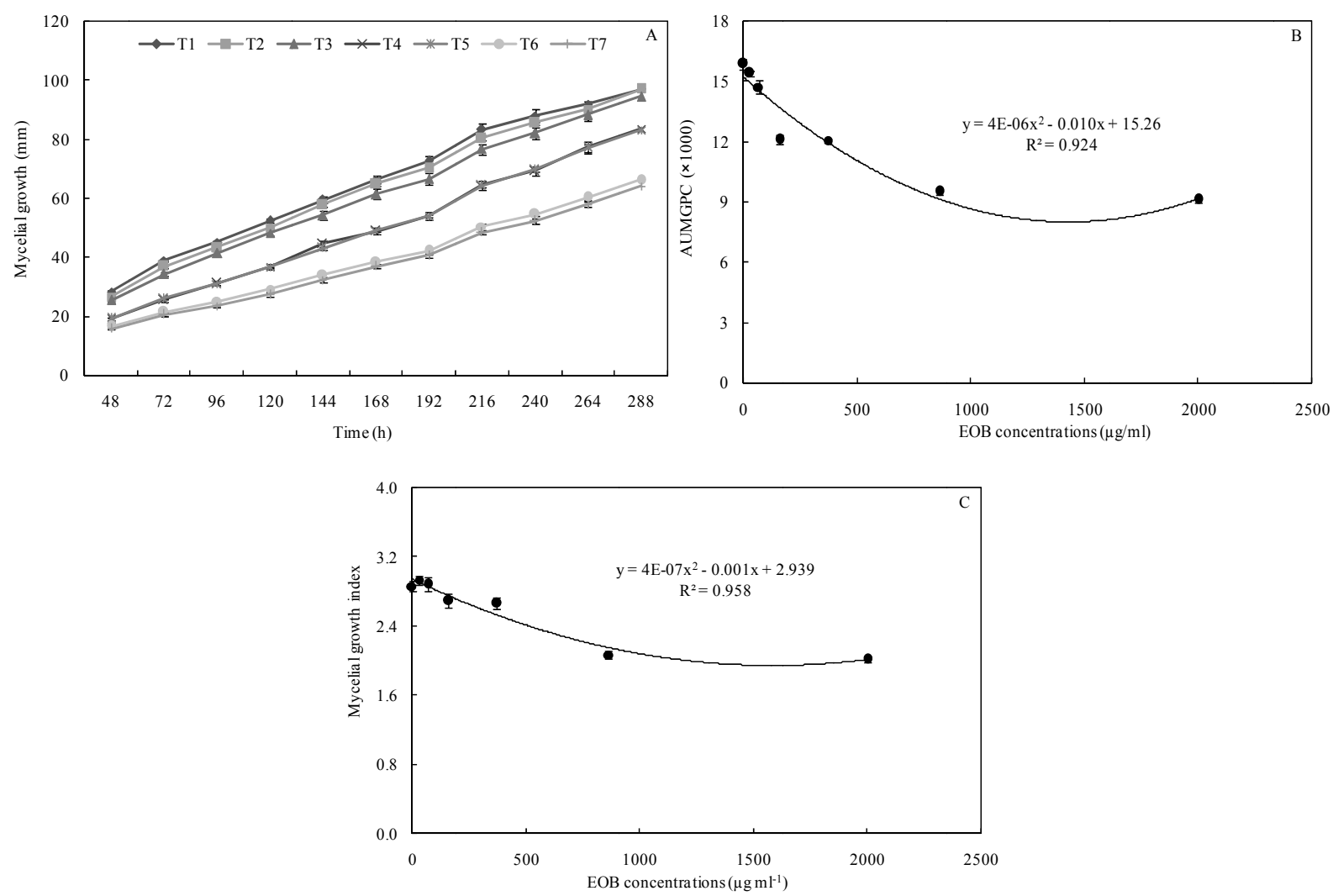

Figure 3. Effect of different concentrations of the essential oil of Baccharis dracunculifolia (EOB) in the mycelial growth of Alternaria alternata $(\mathrm{mm})(\mathrm{A})$, area under the mycelial growth progress curve (B) and mycelial growth índex (C). Treatments included a control without EOB (T1) and the EOB concentrations of 29.99 (T2), 69.47 (T3), 160.92 (T4), 372.73 (T5), 863.38 (T6) or $1999.86 \mu \mathrm{g} \mathrm{mL}^{-1}$ (T7). Bars represent standard errors of the means $(n=5)$

Pitahaya fruits from the control (T1) displayed severe symptoms of Alternaria rot that covered almost thoroughly the fruit surface (Figure 4). Symptoms were water-soaked in appearance and brown to dark in color. Fruits exhibited extensive maceration of the tissue and pulp consistency was lost. A slight decrease in symptoms of Alternaria rot was observed when EOB was applied at 500 (T2) and $1,000 \mu \mathrm{g} \mathrm{mL}^{-1}$ (T3) which was in a sharp contrast with the EOB concentration of $2,000 \mu \mathrm{g} \mathrm{mL}^{-1}$, which almost completely suppressed disease symptoms. The appearance and severity of the Alternaria rot symptoms in fruits that were treated only with the edible coat (T5) were similar to those observed in the control (T1).
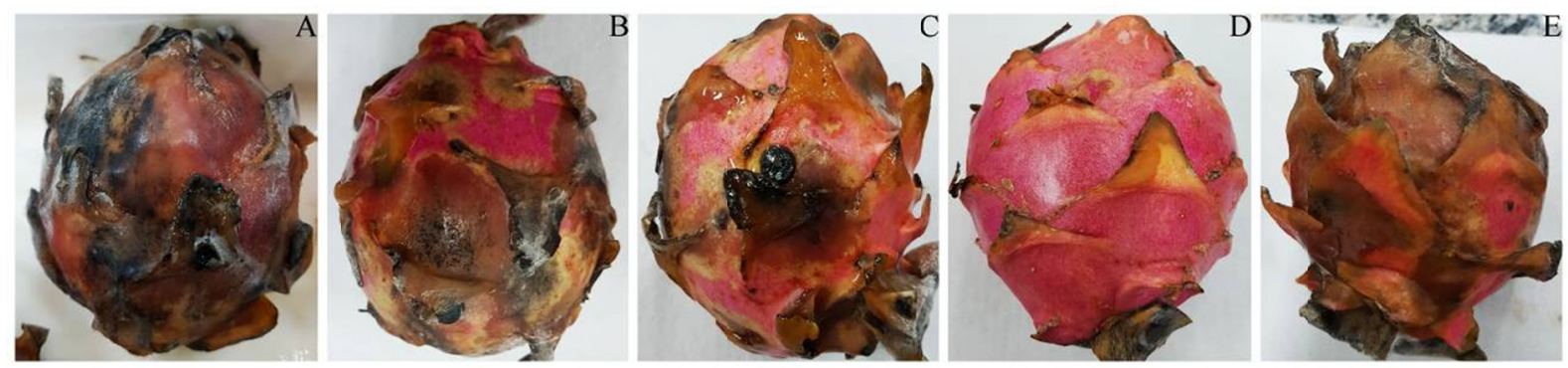

Figure 4. Effect of different concentrations of the essential oil of Baccharis dracunculifolia (EOB) in the

Alternaria rot in pitahaya fruits. Treatments included a negative control with water (A) and the EOB concentrations of 500 (B), 1,000 (C) or 2,000 $\mathrm{g} \mathrm{mL}^{-1}$ (D). The EOB was incorporated into an edible coat based on cassava starch (3\%), $4 \mathrm{~mL}$ sorbitol and $1 \mathrm{~mL}$ Tween 20 . An additional treatment containing only the edible coat served as a positive control (E) 
Lesion area of Alternaria rot was significantly reduced by the EOB regardless of the concentration (Figure 5). The EOB concentrations of 500 (T2) and $1,000 \mu \mathrm{g} \mathrm{mL}^{-1}$ (T3) were similar, decreasing lesion area in 52 and $59 \%$, respectively, relative to the control (T1). The EOB concentration of $2,000 \mu \mathrm{g} \mathrm{mL}^{-1}$ (T4) resulted in the lowest disease intensity, with a 97\% reduction lesion area in comparison to the control (T1). Lesion area did not differ for controls (T1 and T5), indicating that cassava starch did not show an inhibitory activity against $A$. alternata.

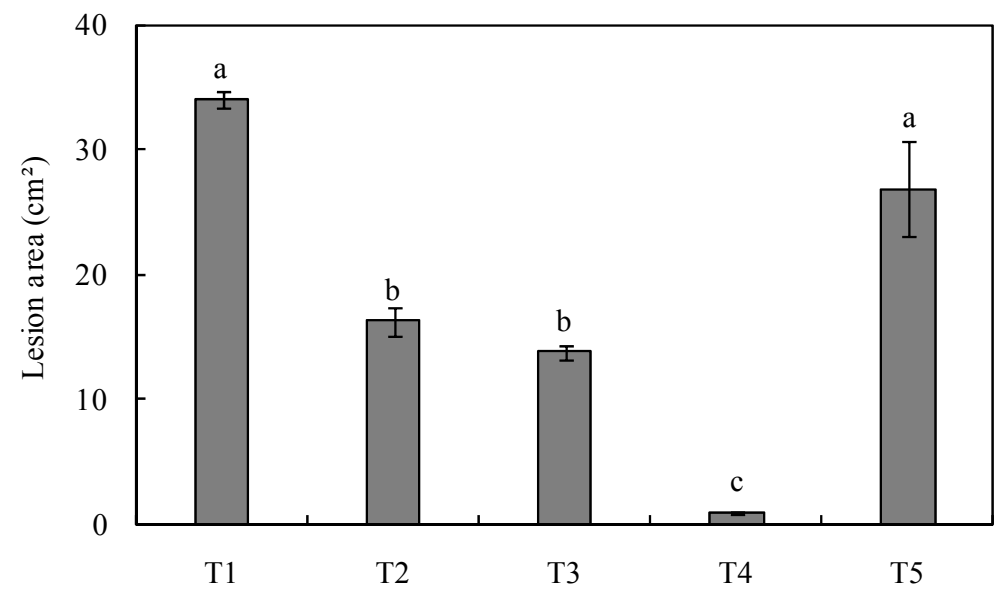

Figure 5. Effect of different concentrations of the essential oil of Baccharis dracunculifolia (EOB) in the lesion area $\left(\mathrm{cm}^{2}\right)$ of Alternaria rot in pitahaya fruits. Treatments included a negative control with water (T1) and the EOB concentrations of 500 (T2), 1,000 (T3) or 2,000 $\mu \mathrm{g} \mathrm{mL}^{-1}$ (T4). EOB were incorporated into an edible coat based on cassava starch (3\%), $4 \mathrm{~mL}$ sorbitol and $1 \mathrm{~mL}$ Tween 20 . An additional treatment containing only the edible coat served as a positive control (T4)

\section{Discussion}

Demand for pitahaya consumptiom has increased sharply over the past few years, mainly owing its health properties. However, its fruits deteriorate rapidly under environmental conditions; rots caused by fungi, including A. alternata, are among the most important factors responsible for that and some essential oils have been investigated for the control of post-harvest diseases (Castro et al., 2017). Despite the essential oil of $B$. dracunculifolia (EOB) have been demonstrated to show antimicrobial activity (Ferronatto et al., 2007; Cazella et al., 2019), studies regarding its potential against plant pathogens are still lacking. Here, we provide novel insights of the potential of EOB in the control of Alternaria rot in pitahaya fruits.

Previous studies demonstrated that EOB displays bacteriostatic and bactericidal activities, mainly against Bacillus cereus, Escherichia coli, Pseudomonas aeruginosa and Staphylococcus aureus, as well as fungistatic and fungicidal activities, including Aspergillus spp., Penicillium spp. and Trichoderma viride (Ferronatto et al., 2007; Cazella et al., 2019). In agreement with these observations, our results showed that EOB inhibited the mycelial growth of $A$. alternata. Nevertheless, the effect of EOB in mycelial growth was found to be dose-dependent; lowest values of AUMGPC and MGI were found with EOB concentrations of 900 and 1,250 $\mu \mathrm{g}$ $\mathrm{mL}^{-1}$, respectively, for experiment 1 , and 500 and $1,250 \mu \mathrm{g} \mathrm{mL}^{-1}$, respectively, for experiment 2 . Studies using a different methodology revealed that minimum inhibitory concentrations (MIC) of EOB for bacteria varied from 0.50 to $12.65 \mathrm{mg} \mathrm{mL}^{-1}$ and for fungi ranged from 8.43 to $16.87 \mathrm{mg} \mathrm{mL}^{-1}$ (Cazella et al., 2019), demonstrating that the antibacterial activity of EOB was more effective than the antifungal one.

Other essential oils rather than EOB have been demonstrated inhibit the growth of plant pathogenic fungi and the inhibitory activity varied according to the essential oil. Investigations of different essential oils against the same fungus we studied in this work (A. alternata) revealed that the most effective essential oils were from Cinnamomum zeylanicum (MIC $=250 \mu \mathrm{g} \mathrm{mL}^{-1}$ ) and Eugenia caryophyllus $\left(\mathrm{MIC}=500 \mu \mathrm{g} \mathrm{mL}^{-1}\right.$ ), followed by Cymbopogon flexuosus, Eucalyptus globulus and Rosmarinus officinalis ( $\mathrm{MIC}=1,000 \mu \mathrm{g} \mathrm{mL}^{-1}$ ) (Castro et al., 2017). In vitro evaluation of antifungal properties of eighteen essential oils added to the fungal growth medium of five pathogens (Lasiodiplodia theobromae, Colletotrichum gloeosporioides, Alternaria citrii, Botrytis cinerea and Penicillium digitatum) isolated from mango, avocado, citrus, grapes and cactus pear showed that Thyme oil was the most effective inhibitor, totally inhibiting all of the pathogens tested at concentrations of $1,000 \mu \mathrm{L}^{-1}$, with the exception of a resistant Penicillium strain (Combrinck et al., 2011). Although A. alternata growth was 
not completely inhibited by EOB in the present study, the pronounced reductions in mycelial growth observed at high doses $\left(>1,000 \mu \mathrm{g} \mathrm{mL}^{-1}\right)$ of EOB indicate its potential to be used in the control of the fungus.

The antimicrobial activity of several essential oils has been linked to the antifungal properties of their constituent compounds. The effective essential oils against $A$. alternata presented considerable amounts of eugenol $(90.5 \%$ for C. zeylanicum and $80.7 \%$ for E. caryophyllus), whereas the lower activity of C. flexuosus, E. globulus and R. officinalis indicated that neral, geranial, 1,8-cineole, limonene, and $\rho$-cymene in, $\alpha$-pinene, 1,8-cineole and camphor were less effective against the fungus (Castro et al., 2017). A high concentration $\left(4,000 \mu \mathrm{L}^{-1}\right)$ of Cymbopogon citratus, whose major constituents were geranial and neral, was required to completely inhibit uredospore germination of Olivea neotectonae (Osorio et al., 2018). Octanoic acid is the major component of noni (Morinda citrifolia) essential oil, which was demonstrated to inhibit different plant pathogenic fungi, including Aspergillus niger, Aspergillus fumigatus, Bipolaris maydis, Colletotrichum gloeosporiodies, Curvularia spp., Exserohilum turcicum, Helminthosporium spp., Olivea neotectonae, Rhizopus oryzae and Sclerotium spp. (Sahoo et al., 2012; Silva et al., 2017; Osorio et al., 2018; Veloso et al., 2018, 2020; Dias et al., 2020). The chemical analysis of the essential oil of the plants that was used in the present study (EOB) showed high proportion of sesquiterpenes in the volatiles samples, such as $\delta$-elemene, germacrene $\mathrm{D}$, bicyclogermacrene, bicyclogermacrene, germacrene D and $\beta$-caryophyllene (Ascari et al., 2019; Brandenburg et al., 2020), whereas spathulenol and trans-nerolidol, both oxygenated sesquiterpenes, were the major compounds found in other study (Cazella et al., 2019). Plant species, climate conditions, soil type, harvesting seasons, age of leaves, geographic region, and extraction process are known to influence the chemical composition of the plant essential oil (Cazella et al., 2019). Some of the sesquiterpenes found in both EOB and other plants are known for their antimicrobial activity against Candida spp., Mycobacterium tuberculosis, Microsporum gypseum and Trichophyton mentagrophytes (Lee et al., 2007; Tan et al., 2016) and nerolidol is the major constituent compound of many plants that display antimicrobial activity (Chan et al., 2016). Therefore, some sequiterpene of B. dracunculifolia is believed to be responsible for the inhibitory activity of EOB observed in vitro against $A$. alternata.

The essential oils have been demonstrated to cause a wide range of structural dysfunctions to fungal hyphae. In $A$. alternata, essential oil of C. flexuosus, C. zeylanicum and E. caryophyllus reduced the growth and caused different structural changes, such as hyphae disruption, extravasation of cell content, deformation of the integrity of the hyphae, and tumescence of the hyphae with the possible formation of adhesive mucilage (Castro et al., 2017). Although the mechanisms of action of essential oils against A. alternata are not completely understood, their lipophilic nature allows them to interact with cell membranes, thereby increasing the permeability and disturbing these structures (Lima et al., 2019). The essential oils constituents can interfere with electron transport chain, thereby reducing ATP production, besides affecting enzyme systems, granulate the cytoplasm, extravasation of cellular content and production of reactive oxygen species, which, in turn, damage cell membranes, DNA, proteins, and lipids and finally caused fungal death (Rasooli et al., 2006; Costa et al., 2011; Veloso et al., 2020).

The edible coat containing EOB was found to decrease symptoms of Alternaria rot in pitahaya fruits. Decreases in lesion area of Alternaria rot ranged from $52 \%$ at $500 \mu \mathrm{g} \mathrm{mL}^{-1}$ to $97 \%$ at $2,000 \mu \mathrm{g} \mathrm{mL}^{-1}$ of EOB. These findings are in line with previous reports that observed decreases in postharvest diseases as a result of EO treatment. The area under anthracnose progress curve in papaya fruits was reduced by Essential oils from C.citratus and E. citriodora, Lippia sidoides and M. citrifolia (Carnelossi et al., 2009; Dias et al., 2020). The Essential oils from E. cariophyllus and $C$. zeylanicum at 500 or $1,000 \mu \mathrm{g} \mathrm{mL}^{-1}$ inhibited mycelial growth of $A$. alternata by $26-31 \%$ on the epidermis of pitahaya fruits (Castro et al., 2017). The association of paraffin + noni, gelatin + octanoic acid and suflower oil + thymol decreased the area under anthracnose progress curve in papaya fruits and disease control was suggested to be a result of the combined action of both coat and essential oil constituents (Dias et al., 2020), which is somewhat different of our findings, in which we did not observe a significant effect for cassava starch coat. Interestingly, we observed that decreases in lesion area greatly surpassed those observed in mycelial growth; while mycelial growth was reduced by $34 \%$ at $2,000 \mu \mathrm{g} \mathrm{mL}^{-1}$, there was a $97 \%$ decrease in lesion area. This finding indicates that other mechanism(s) beyond the direct effect of EOB in the fungus may be involved in decreasing Alternaria rot symptoms in pitahaya fruits; most likely, EOB can prime pitahaya fruits for enhanced defense against $A$. alternata infection. Accordingly, essential oils have been demonstrated to induce a wide range of defense responses when applied before pathogen infection. The defense-related genes, such as those encoding pathogenesis-related (PR-1) proteins, WRKY transcription factors, thaumatinlike protein, lipoxygenase, ethylene response factor and chitinase, were differentially expressed in tomato plants that were treated with essential oil from fennel seeds (Foeniculum vulgare), which was behind a decrease of $42 \%$ in Fusarium wilt severity in comparison to plants that were not treated with essential oil (Kalleli et al., 2020). Similarly, decreases in 
incidence and severity of brown rot severity in peach treated with thyme oil were associated to higher activities of defense-related enzymes, including $\beta$-1,3-glucanase, chitinase, phenylalanine ammonia-lyase and polyphenol oxidase besides increased phenol content, which is known to play a major role in plant defense against pathogen invasion (Cindi et al., 2016). Based on our findings, EOB is believed to have a dual mode of action in the control of Altenaria rot in pitahaya through an antifungal activity as well as by inducing defense responses in fruits. The latter activity is particularly important for the management of postharvest diseases since the activity of EOB as an elicitor molecule may wide its spectrum of control against other rotting fungi.

\section{Conclusions}

Our results demonstrated that the essential oil of $B$. dracunculifolia (EOB) displays antifungal activity against $A$. alternata. The EOB incorporated into an edible coat supresses almost completely the symptoms of Alternaria rot in pitahaya fruits. Data from the present study shed light on the potential of EOB as an ecofriendly and effective tool to be included in the management of postharvest diseases, which can lengthen the shelf life of pitahaya fruits.

\section{Acknowledgements}

D. Debona is very grateful to the fellowship granted by Fundação Araucária to the undergraduate students A. Pivotto and A. J. Tetzlaff. Authors also thank to Universidade Tecnológica Federal do Paraná-Câmpus Santa Helena for providing the facilities in which experiments were performed.

\section{References}

Ascari, J., de Oliveira, M. S., Nunes, D. S., Granato, D., Scharf, D. R., Simionatto, E., ... Heiden, G. (2019). Chemical composition, antioxidant and anti-inflammatory activities of the essential oils from male and female specimens of Baccharis punctulata (Asteraceae). Journal of Ethnopharmacology, 234, 1-7. https://doi.org/10.1016/j.jep.2019.01.005.

Brandenburg, M. M., Rocha, F. G., Pawloski, P. L., Soley, B. S., Rockenbach, A., Scharf, D. R., ... Otuki, M. F. (2020). Baccharis dracunculifolia (Asteraceae) essential oil displays anti-inflammatory activity in models of skin inflammation. Journal of Ethnopharmacology, 259, 112840. https://doi.org/10.1016/j.jep.2020. 112840

Carnelossi, P. R., Schwan-Estrada, K. R. F., Cruz, M. E. S., Itako, A. T., \& Mesquini, R. M. (2009). Essential oils for postharvest control of Colletotrichum gloessential oilsporioides in papaya. Brazilian Journal of Medicinal Plants, 11(4), 399-406. https://doi.org/10.1590/S1516-05722009000400007

Castro, J. C., Endo, E. H., Souza, M. R., Zanqueta, E. B., Polonio, J. C., Pamphile, J. A., ... Abreu Filho, B. A. (2017). Bioactivity of essential oils in the control of Alternaria alternata in dragon fruit (Hylocereus undatus Haw.). Industrial Crops and Products, 97, 101-109. https://doi.org/10.1016/j.indcrop.2016.12.007

Cazella, L. N., Glamoclija, J., Soković, M., Gonçalves, J. E., Linde, G. A., Colauto, N. B., \& Gazim, Z. C. (2019). Antimicrobial activity of essential oil of Baccharis dracunculifolia DC (Asteraceae) aerial parts at flowering period. Frontiers in Plant Science, 10, 27. https://doi.org/10.3389/fpls.2019.00027

Chaemsanita, S., Matan, N., \& Matan, N. (2018). Effect of peppermint oil on the shelf-life of dragon fruit during storage. Food Control, 90, 172-179. https://doi.org/10.1016/j.foodcont.2018.03.001

Chan, W. K., Tan, L. T. H., Chan, K. G., Lee, L. H., \& Goh, B.-H. (2016). Nerolidol: A sesquiterpene alcohol with multi-faceted pharmacological and biological activities. Molecules, 21(5), e529. https://doi.org/ 10.3390/molecules21050529

Cindi, M. D., Soundy, P., Romanazzi, G., \& Sivakumar, D. (2016). Different defense responses and brown rot control in two Prunus persica cultivars to essential oil vapours after storage. Postharvest Biology and Technology, 119, 9-17. https://doi.org/10.1016/j.postharvbio.2016.04.007

Combrinck, S., Regnier, T., \& Kamatou, G. P. P. (2011). In vitro activity of eighteen essential oils and some major components against common postharvest fungal pathogens of fruit. Industrial Crops and Products, 33(2), 344-349. https://doi.org/10.1016/j.indcrop.2010.11.011

Cos, P., De Bruyne, T., Hermans, N., Apers, S., Berghe, D. V., \& Vlietinck, A. J. (2004). Proanthocyanidins in health care: Current and new trends. Curr Med Chem, 11(10), 1345-1359. https://doi.org/10.2174/0929867 043365288

Costa, A. R. T., Amaral, M. F. Z. J., Martins, P. M., Paula, J. A. M., Fiuza, T. S., Tresvenzol, L. M. F., ... Bara, M. T. F. (2011). Action of Syzygium aromaticum (L.) Merr. \& L.M. Perry essential oil on the hyphae of some 
phytopathogenic fungi. Revista Brasileira de Plantas Medicinais, 13, 240-245. http://dx.doi.org/10.1590/ S1516-05722011000200018

Dias, B. L., Costa, P. F., Dakin, M. S., Mourão, D. S. C., Dias, F. R., Sousa, R. R., ... Santos, G. R. (2020). Control of papaya fruits anthracnose by essential oils of medicinal plants associated to different coatings. Journal of Medicinal Plant Research, 14(6), 239-246. https://doi.org/10.5897/JMPR2019.6838

Ferronatto, R., Marchesan, E. D., Pezenti, E., Bednarski, F., \& Onofre, S. B. (2007). Atividade antimicrobiana de ólessential oils essenciais produzidos por Baccharis dracunculifolia D.C. e Baccharis uncinella D.C. (Asteraceae). Revista Brasileira de Farmacognosia, 17(2), 224-230. https://doi.org/10.1590/S0102-695X 2007000200016

Freitas, S. T., \& Mitcham, E. J. (2013). Quality of pitaya fruit (Hylocereus undatus) as influenced by storage temperature and packaging. Scientia Agricola, 70(4), 257-262. https://doi.org/10.1590/S0103-9016201300 0400006

Garganese, F., Schena, L., Siciliano, I., Prigigallo, M. I., Spadaro, D., Grassi, A., ... Sanzani, S. M. (2016). Characterization of citrus associated Alternaria species in mediterranean areas. PLOS ONE, 11(9), e0163255. https://doi.org/10.1371/journal.pone.0163255

Kalleli, F., Abid, G., Salem, I. B., Boughalleb-M'hamdi, N., \& M'hamdi, M. (2020). Essential oil from fennel seeds (Foeniculum vulgare) reduces Fusarium wilt of tomato (Solanum lycopersicon). Phytopathologia Mediterranea, 59(1), 63-76. https://doi.org/10.14601/Phyto-11143

Kim, H., Choi, H. K., Moon, J. Y., Kim, Y. S., Mosaddik, A., \& Cho, S. K. (2011). Comparative antioxidant and antiproliferative activities of red and white pitayas and their correlation with flavonoid and polyphenol content. Journal of Food Science, 76(1), 38-45. https://doi.org/10.1111/j.1750-3841.2010.01908.x.

Lee, S. J., Han, J. I., Lee, G. S., Park, M. J., Choi, I. G., Na, K. J., \& Jeung, E. B. (2007). Antifungal effect of eugenol and nerolidol against Microsporum gypseum in a guinea pig model. Biological and Pharmaceutical Bulletin, 30(1), 184-188. https://doi.org/10.1248/bpb.30.184

Lima, C. B., Rentschler, L. L. A., Bueno, J. T., \& Boaventura, A. C. (2016). Plant extracts and essential oils on the control of Alternaria alternata, Alternaria dauci and on the germination and emergence of carrot seeds (Daucus carota L.). Ciência Rural, 46(5), 764-770. https://doi.org/10.1590/0103-8478cr20141660

Lima, C. V. R., Neves, F. J. M., Maior, L. P. S., Pires, L. L. S., Rocha, T. J. M., \& Santos, A. F. (2019). Antibacterial action of the essential oil of leaves of Eucalyptus globulus, against multiresistant pathogens. Diversitas Journal, 4(1), 242-252. https://doi.org/10.3109/13880209.2011.553625

Massignani, J. J., Lemos, M., Maistro, E. L., Schaphauser, H. P., Jorge, R. F., Sousa, J. P., ... de Andrade, S. F. (2009). Antiulcerogenic activity of the essential oil of Baccharis dracunculifolia on different experimental models in rats. Phytotherapy Research, 23(10), 1355-1360. https://doi.org/10.1002/ptr.2624

Mizrahi, Y., Nerd, A., \& Nobel, P. S. (1997). Cacti as crops. Horticultural Reviews, 18, 291-320. https://doi.org/10.1002/9780470650608.ch6

Nguefack, J., Wulff, G. E., Dongmo, J. B. L., Fouelefack, F. R., Fotio, D., Mbo, J., \& Torp, J. (2013). Effect of plant extracts and an essential oil on the control of brown spot disease, tillering, number of panicles and yield increase in rice. European Journal of Plant Pathology, 137, 871-882. https://doi.org/10.1007/ s10658-013-0298-0

Ortiz-Hernández, Y. D., \& Carrillo-Salazar, J. A. (2012). Pitahaya (Hylocereus spp.): A short review. Comunicata Scientiae, 3(4), 220-237. https://doi.org/10.14295/cs.v3i4.334

Osorio, P. R. A., Leão, E. U., Veloso, R. A., Mourão, D. S. C., \& Santos, G. R. (2018). Essential oils for alternative teak rust control. Floresta e Ambiente, 25(2), e20160391. https://doi.org/10.1590/2179-8087. 039116

Rasooli, L., Rezaei, M. B., \& Allameh, A. (2006). Growth inhibition and morphological alterations of Aspergillus niger by essential oils from Thymus eriocalyx and Thymus x-prolock. Food Control, 17(5), 359-364. https://doi.org/10.1016/j.foodcont.2004.12.002

Sahoo, K., Dhal, N. K., Sahoo, S. L., \& Lenka, S. S. (2012). Comparative phytochemical and antimicrobial study of Morinda pubescens SM. and Morinda citrifolia L. International Journal of Pharmacy and Pharmaceutical Sciences, 4(3), 425-429. Retrieved from https://innovareacademics.in/journal/ijpps/ Vol4Suppl3/3821.pdf 
Silva, J. C. E., Mourão, D. D. S. C., Lima, F. S. O., Sarmento, R. D. A., Dalcin, M. S., Aguiar, R. W. S., \& Santos, G. R. (2017). The efficiency of noni (Morinda citrifolia L.) essential oil on the control of leaf spot caused by Exserohilum turcicum in maize culture. Medicines, 4, 60. https://doi.org/10.3390/medicines4030060

Stahl, E., \& Schild, W. (1981). Drogenanalyse II: Inhaltsstoffe and Isolierungen. Verlag: Gustav Fischer.

Stintzing, F. C., Schieber, A., \& Carle, R. (2002). Betacyanins in fruits from red-purple pitaya, Hylocereus polyrhizus (Weber) Britton \& Rose. Food Chemistry, 77(1), 101-106. https://doi.org/10.1016/S0308-8146 (01)00374-0

Tan, N., Satana, D., Sem, B., Tan, E., Altan, H. B., Demirci, B., \& Uzum, M. (2016). Antimycobacterial and antifungal activities of selected four Salvia species. Records of Natural Products, 10(5), 593-603. Retrieved from https://acgpubs.org/doc/2018080807173171-RNP-1508-159.pdf

Veloso, R. A., Ferreira, T. P. S., Debona, D., Aguiar, R. W. S., Cangussu, A. S. R., Chagas Junior, A. F., Santos, G. R. (2018). Enzimatic activity in essential oil treated and pathogen inoculated corn plants. Journal of Agricultural Science, 10(10), 171-177. https://doi.org/10.5539/jas.v10n10p171

Veloso, R. A., Ferreira, T. P. S., Dias, B. L., Mourão, D. S. C., Barros, A. M., Ferreira, T. P. S., ... Santos, G. R. (2020). Chemical composition and bioactivity of essential oil from Morinda citrifolia L. fruit. Journal of Medicinal Plants Research, 14(5), 208-214. https://doi.org/10.5897/JMPR2019.6853

Wahdaningsih, S., Wahyuono, S., Riyanto, S., \& Murwanti, R. (2020). Terpenoid-lupeol of red dragon fruit (Hylocereus polyrhizus) and its immunomodulatory activity. Pakistan Journal of Pharmaceutical Sciences, 33(2), 505-510. https://doi.org//10.36721/PJPS.2020.33.2.REG.505-510.1

Wybranice, S., Nowak-Wydra, B., Mitka, K., Kowalski, P., \& Mizrahi, Y. (2007). Minor betalains in fruits of Hylocereus species. Phytochemistry, 68(2), 251-259. https://doi.org/10.1016/j.phytochem.2006.10.002

\section{Copyrights}

Copyright for this article is retained by the author(s), with first publication rights granted to the journal.

This is an open-access article distributed under the terms and conditions of the Creative Commons Attribution license (http://creativecommons.org/licenses/by/4.0/). 